\title{
Faktor-Faktor yang Mempengaruhi Partisipasi Pemangku Kepentingan pada Pengembangan Kawasan Wisata Kedung Ombo
}

\author{
Nafiah Ariyani ${ }^{1}$, Akhmad Fauzi $^{2}$, Farhat Umar3 \\ Affiliation \\ ${ }^{1}$ Magister Management Program, Sahid University, Jakarta; ${ }^{2}$ Regional and Rural \\ Development Planning Program, IPB University, Bogor; ${ }^{3}$ Industrial Engin eering Faculty, \\ Universitas Sahid, Jakarta.
}

\section{Correspondence}

Nafiah Ariyani. Magister Management Program, Sahid University. Sahid Sudirman

Residence, Lt. 5, Jl. Jendral Sudirman No. 86, Jakarta. Email: nafiah_ariyani@usahid.ac.id.

\begin{abstract}
Stakeholder participation in tourism development is an important factor in line with the characteristics of tourism which involves many actors with various diverse interests. The differences in the character and interests of the actors resulted in the interest in participating not automatically. This study aims to determine the determinants of interest in participation and the typology of stakeholders in developing the tourist area of Kedung Ombo. Using the mix-method paradigm, this study describes an ex-ante case. Data collection used FGD, interviews, and questionnaires. Data analysis used the Qualitative Comparative Analysis (QCA) assisted by Tosmana software version 1.52. The results showed there are four factors that shape stakeholder participation, namely: 1 Stakeholders' mindset towards tourism and its multiplier effect. 2. The capacity of stakeholders in providing budget, human resources, technical support, and develop ment of tourist attractions. 3. Good relations between stakeholders. 4. Confidence in the ability of the tourist area of Kedung Ombo to facilitate common interests. The typology of stakeholders based on interest in participating is divided into two groups, namely interested in participating and not interested in participating, the re are no contradictory stakeholders. Eleven stakeholders out of fifteen are interested to participate. This finding is useful as a basis for developingstakeholder engagement, which is one of the important conditions in developing a sustainable Kedung Ombo tourism area.
\end{abstract}

Keywords: Kedung Ombo; Participation; Stakeholders; QCA.

Article Information

Submitted 17 Oktober 2020 | Revised 28 Januari 2021 | Accepted 17 Februari 2021

Recommended Citation: Ariyani, N., Fauzi, A., Umar, F. (2020). Faktor-Faktor yang Mempengaruhi Partisipasi Pemangku Kepentingan pada Pengembangan Kawasan Wisata Kedung Ombo. Jurnal Pariwisata Terapan, 4 (2), 147-162.

https://doi.org/10.22146/jpt.60678

Copyright (c) 2020 by the author(s). This article is published by Universitas Gadjah Mada, Indonesia under the Creative Commons Attribution (CC BY 4.0) license. Anyone may reproduce, distribute, translate, and create derivative works of this article (for both commercial and noncommercial purposes), subject to full attribution to the original publication and author(s). The full terms of this license may be seen at http://creativecommons.org/licenses/by/4.0/legalcod 


\section{Pendahuluan}

Isu tentang keterlibatan pemangku kepentingan pada pengembangan pariwisata secara berkelanjutan menjadi isu yang semakin penting seiring dengan penerapan konsep pengambilan kebijakan publik yang semakin melibatkan banyak pihak. Partisipasi, komitmen, tanggungjawab, rasa memiliki dari para pemangku kepentingan merupakan kunci untuk membangun sinergi dan konvergensi yang sangat diperlukan untuk mewujudkan tata kelola destinasi pariwisata yang baik. Beberapa literatur mengkonfirmasi bahwa pengembangan pariwisata yang berhasil lahir dari perencanaan yang cermat yang didukung oleh partisipasi seluruh pemangku kepentingan (Nabiha \& Hasliza, 2015).

Salah satu kunci keberhasilan implementasi pembangunan pariwisata berkelanjutan adalah dukungan dari stakeholders (McComb, Boyd \& Boluk, 2017). Pelibatan berbagai elemen pemangku kepentingan diperlukan pada seluruh proses pengembangan sejak perencanaan melalui pendekatan perencanaan partisipatif hingga tahap operasi dan evaluasi. Partisipasi dan keterlibatan pemangku kepentingan akan membantu mengurangi konflik kepentingan berkaitan dengan banyaknya pihak yang terlibat dalam sistem pariwisata dengan kepentingan yang beragam.

Beberapa peneliti terdahulu menyatakan, partisipasi dan pelibatan pemangku kepentingan akan membantu mengembangkan komitmen dan kapasitas kolektif dalam mengubah ide dan rencana menjadi sebuah tindakan nyata Charleen \& Forbes (2014). Pelibatan pemangku kepentingan akan menghasilkan pengambilan keputusan yang lebih baik, mewujudkan alokasi sumber daya yang lebih baik dan meningkatkan kapasitas operasionalisasi destinasi pariwisata (Fathimath, 2015). Pelibatan pemangku kepentingan tidak hanya akan menghasilkan keputusan yang responsif terhadap kepentingan dan stakeholders value, tetapi juga membantu menyelesaikan konflik, membangun kepercayaan dan mendidik tentang lingkungan (Gregory et al., 2020). Pernyataan dari para peneliti ini meyakinkan bahwa partisipasi dan pelibatan pemangku kepentingan harus ada demi keberhasilan pembangunan pariwisata yang berkelanjutan.

Sebagai sektor yang mempunyai karakteristik multidimensional (meliputi multi sektor, multi aktor, multi wilayah dan multi aspek), kompleksitas dan ketidakpastian sangat mewarnai sektor pariwisata. Oleh karena itu, keterlibatan pemangku kepentingan dalam proses pengambilan keputusan maupun dalam operasionalisasi pengelolaan pariwisata dianggap sebagai tonggak yang tepat dalam pengambilan langkah kebijakan pada sektor ini (Leal Filho \& Londero Brandli, 2016). Namun demikian, meskipun kesadaran terhadap pentingnya keterlibatan pemangku kepentingan semakin tumbuh, dalam faktanya hal tersebut menjadi kompleks, sulit bahkan seringkali gagal (McComb, Boyd \& Boluk, 2017). Kekurangpemahaman tentang implikasi dari partisipasi pemangku kepentingan serta bagaimana memperbaiki prosesnya menjadi tantangan sendiri. Pada penelitiannya di Penang Malaysia, Siti Nabiha dan Noor Haslizaa menemukan bahwa proses pelibatan pemangku kepentingan rumit dan bermasalah. Penyebab utamanya adalah ketidakjelasan tentang peran dan tanggung jawab dari banyak entitas yang terlibat serta kurangnya strategi yang jelas baik di tingkat negara bagian maupun lokal (Nabiha \& Hasliza, 2015).

Beberapa faktor yang dianggap menjadi hambatan dalam pendekatan partisipatif, yaitu kurangnya kemauan politik pengambil kebijakan pada tahap perencanaan karena 
implikasinya terhadap distribusi kekuatan dan sumber daya serta kurangnya partisipasi dan kesadaran dari pemangku kepentingan pada tahap pelaksanaan (Kala \& Bagri, 2018). Agar berhasil, implementasi tehadap konsep partisipasi membutuhkan beberapa prasyarat, yaitu jejaring yang kuat, tingkat kepercayaan yang memadai, dan akuntabilitas dari masingmasing aktor (Kurniasih, 2017). Dari perspektik karakter negara, tantangan dalam implementasi konsep partisipasi pemangku kepentingan lebih menguat di negara berkembang dibandingkan negara maju karena umumnya di negara berkembang sifatnya "tokenistic" (Tosun, 2006).

Penelitian ini bertujuan untuk mengidentifikasi faktor-faktor yang menentukan minat partisipasi dari pemangku kepentingan pada pengembangan kawasan wisata Kedung Ombo. Waduk Kedung Ombo merupakan bendungan terbesar se Asia (6.576 Ha yang terdiri dari lahan perairan seluas $2.830 \mathrm{Ha}$ dan lahan dataran seluas $3.746 \mathrm{Ha}$ ). Waduk ini terletak di tiga wilayah kabupaten, yaitu Kabupaten Grobogan, Kabupaten Sragen dan Kabupaten Boyolali (Gambar 1).

Kawasan waduk Kedung Ombo sangat ideal untuk dikembangkan sebagai destinasi pariwisata, hal itu terkait dengan lokasi waduk yang berada pada hutan yang sangat luas dengan udara yang sejuk dan panorama yang indah. Keberadaan kawasan wisata di wilayah ini akan sangat bermanfaat dalam meningkatkan infrastruktur, kegiatan ekonomi masyarakat, perluasan lapangan kerja sekaligus menjadi sumber pendapatan daerah. Namun mengingat banyaknya pihak yang berkepentingan di kawasan ini, sementara koordinasi sangat terbatas (hasil wawancara dengan informan) maka pemanfaatan potensi pariwisata yang maupun pengembangannya lambat.

Upaya untuk memanfaatkan potensi pariwisata sebenarnya telah dilakukan oleh beberapa pihak, diantaranya Pemerintah Kabupaten (Pemkab) Grobogan, Pemkab Sragen, Perhutani, pemerintah desa dan masyarakat. Namun upaya tersebut masih sangat terbatas dibandingkan dengan besarnya potensi yang tersedia. Spot-spot wisata yang telah ada diantaranya Wisata Rintisan Wonosari di Desa Rambat Kabupaten Grobogan, Wana Wisata Kedung Cinta di Desa Wonoharjo Kabupaten Boyolali, dan Desa Wisata Boyolayar di Kabupaten Sragen. Spot-spot tersebut kondisi sarana dan prasarana pariwisatanya sangat terbatas sehingga kurang menarik wisatawan dan tidak berkelanjutan sehingga sangat memerlukan pembenahan.

Memanfaatkan potensi pariwisata kawasan Kedung Ombo secara optimal, memerlukan pelibatan seluruh pemangku kepentingan dalam kerangka kerjasama dan saling menguntungkan. Partisipasi seluruh pemangku kepentingan dalam proses pengembangan akan mendukung ketersediaan sumber daya yang diperlukan, kapasitas serta pemikiran yang cukup sehingga keberhasian dan keberlanjutannya relatif terjamin. Namun demikian perlu disadari bahwa partisipasi para pemangku kepentingan bukanlah suatu keadaan yang terjadi secara otomatis, melainkan perlu dibangun dan dikembangkan. Partisipasi juga dipengaruhi oleh banyak faktor dan berbeda antar berbagai situasi (Tosun, 2006). Penelitian ini mengembangkan model kausalitas antara faktor-faktor yang menentukan minat partisipasi dengan tingkat partisipasi para pemangku kepentingan di kawasan Kedung Ombo. Hasil penelitian diharapkan menjadi masukan bagi para pengambil kebijakan di wilayah ini dalam mengembangkan potensi pariwisata Kedung Ombo secara partisipatif dan berkelanjutan. 


\section{Konseptualisasi Variabel Penelitian}

Partisipasi pemangku kepentingan dapat didiskripsikan sebagai proses dimana seluruh aktor pemangku kepentingan dari suatu sistem dapat terlibat dan membentuk inisiatif pada proses pengembangan suatu sistem. Dua kata yang dekat dengan partisipasi adalah keterikatan (engagement) dan keterlibatan (involvement) yang mencerminkan intensitas dari partisipasi Agar partisipasi pemangku kepentingan dapat terwujud maka antusiasme terhadap pola kerja kemitraan, keterikatan dan keterlibatan harus dipupuk dengan sungguhsungguh.

Mengadopsi pemikiran Freeman, pemangku kepentingan pariwisata adalah kelompok atau individu apa saja yang dapat mempengaruhi atau dipengaruhi oleh pengembangan pariwisata di suatu daerah (Freeman, R.E.. McVea, 2001). Sesuai karakteristiknya, pemangku kepentingan adalah entitas yang mempunyai kebebasan untuk menetapkan tujuan sendiri dan melakukan tindakan strategis untuk mencapai tujuan tersebut (Heger \& Rohrbeck, 2012). Independensi pemangku kepentingan menjadi salah satu faktor sulitnya pemangku kepentingan berkomitmen terhadap kerja kolaboratif karena tujuan yang seringkali saling berbenturan (Baggio, Scott, \& Cooper, 2010).

Agar partisipasi para pemangku kepentingan dapat dibangun maka diperlukan batasan yang jelas tentang ruang lingkup keterlibatan dan bagaimana proses partisipasi tersebut diindentifikasi (Stratigea, 2013). Beberapa faktor berikut ini dapat dijadikan pertimbangan. Pertama, tidak semua pemangku kepentingan perlu dilibatkan secara setara, tetapi perlu diidentifikasi dan dipahami keterkaitan seluruh pemangku kepentingan dengan misi pengembangan (Donaldson, T. \& Preston, 1995). Kedua, partisipasi pemangku kepentingan bervariasi sesuai tujuan dan harapan masing-masing pemangku kepentingan (Tosun, Hatay, \& Timothy, 1998). Ketiga, luasnya ruang lingkup keterlibatan kepentingan pemangku kepentingan harus diidentifikasi karena mengakibatkan kegagalan proses pengembangan (Clarkson, 1995). Keempat, tingkat partisipasi harus disesuaikan dengan kapasitas kelembagaan dan minat untuk berkolaborasi dari masing-masing pemegang kepentingan (Gray, 1989).

Keterlibatan pemangku kepentingan memegang peranan penting sejak tahap pembuatan kebijakan hingga tahap implementasi proyek (Turker, Alaeddinoglu, \& Can, 2016). Tingkat keterlibatan pemangku kepentingan kemungkinan berbeda, tergantung pada potensi kelembagaan masing-masing (Donaldson, T. \& Preston, 1995). Beberapa pemangku kepentingan mungkin hanya bertanggung jawab untuk merumuskan kebijakan, sementara yang lain menerapkan kebijakan pariwisata (Miller, Rathouse, Scarles, Holmes, \& Tribe, 2010). Terkait dengan hal itu, (Charleen \& Forbes, 2014) membedakan pemangku kepentingan dalam tiga tingkatan yang harus saling terhubung guna mewujudkan pengembangan pariwisata yang berhasil (Gambar 2).

Meskipun partisipasi aktif para pemangku kepentingan dalam perencanaan dan pengembangan pariwisata telah dijalankan di berbagai negara maju, namun di negaranegara berkembang ditemukan bahwa praktik tersebut bersifata sal-asalan (tokenistic) (Tosun, 2000). Studi tentang peran pemerintah daerah dalam pengembangan pariwisata berkelanjutan di Queensland ditemukan bahwa partisipasi publik yang bersifat tokenistik di 
disebabkan peran dan kekuatan pemerintah daerah yang terlalu kuat dan justru bertindak sebagai penghalang bagi pengembangan pariwisata berkelanjutan (Ruhanen, 2012).

Keterlibatan pemangku kepentingan dalam pengembangan pariwisata berbeda antar berbagai negara dan tergantung pada banyak elemen. Hasil penelitian di Thailand menunjukkan faktor-faktor penentu partisipasi pemangku kepentingan adalah modal sosial dan kepercayaan politik (Hemaphan, 2017). Hasil penelitiandi County Cornwall Inggris faktor-faktor kunci yang memungkinkan keterlibatan pemangku kepentingan adalah kualitas kepemimpinan, kualitas dan aksesibilitas informasi, dan prioritas implementasi. Sedangkan faktor-faktor yang meningkatkan keterlibatan pemangku kepentingan adalah pola pikir pemangku kepentingan, kapasitas keterlibatan, hubungan antar pemangku kepentingan dan kemampuan beradaptasi pemangku kepentingan (Waligo, Clarke, \& Hawkins, 2013).

Penelitian di Penang Malaysia menemukan faktor penghalang partisipasi pemangku kepentingan adalah sumber daya keuangan yang tidak memadai, keterbatasan keahlianpengalaman dan kompetensi, otoritas perencanaan pariwisata, dan kurangnya komitmen. Sedangkan faktor yang menghambat keberhasilan keterlibatan pemangku kepentingan adalah tingkat kesadaran yang rendah, perasaan tidak berdaya, masalah yang terkait dengan koordinasi dan birokrasi, kerapuhan kepentingan bersama, ketidakmampuan pemangku kepentingan untuk mengklarifikasi tujuan, dan keengganan untuk membuat perubahan signifikan terhadap perilaku (Nabiha \& Hasliza, 2015).

Temuan penelitian pada perencanaan pariwisata di Kepulauan Langkawi, Malaysia, menunjukkan faktor yang menghambat partisipasi adalah informasi yang tidak memadai, pendekatan yang tidak efektif, sikap penduduk, dan pengecualian pada proses partisipasi. Partisipasi publik juga hanya terjadi pada tahap awal proses perencanaan yang disebabkan keterbatasan struktural dan operasional (Marzuki, Hay, \& James, 2012). Sementara penelitian yang dilakukan di Morness Irlandia Utara, menemukan alasan kurangnya keterlibatan dan kolaborasi pemangku kepentingan adalah kurangnya pemahaman terhadap pariwisata, kurangnya kekuatan dalam pengambilan keputusan, tidak adanya pendekatan jangka panjang menuju kolaborasi, dan kurangnya visi dan tujuan bersama (McComb et al., 2017).

Faktor-faktor yang utama yang membentuk keterlibatan pemangku kepentingan dalam pengembangan pariwisata, yaitu: (1) kesadaran terhadap konteks partisipasi; (2) kesadaran terhadap ragam tingkat partisipasi dan integrasi secara vertikal dan horizontal; (3) komitmen untuk mengembangkan partisipasi serta struktur koordinasi; (4) pengembangan pola kemitraan untuk memastikan partisipasi pemangku kepentingan yang lebih luas dan efektif (Charleen \& Forbes, 2014). Berbagai hasil penelitian tersebut dapat menjadi rujukan dalam mengidentifikasi faktor-faktor yang membentuk partisipasi pemangku kepentingan dalam mengembangkan kawasan wisata Kedung Ombo.

\section{Metode}

Penelitian ini menggunakan paradigma kualitatif-kuantitatif untuk menjelaskan fenomena partisipasi pemangku kepentingan. Pengumpulan data dilakukan dengan beberapa metode untuk mengeskplorasi situasi saat ini sekaligus menjangkau kemungkinan pada masa yang akan datang karena sifat kasus adalah ex-ante. Metode tersebut adalah: 1. Diskusi 
Kelompok Terarah untuk menentukan faktor-faktor yang diperkirakan mempengaruhi minatberpartisipasi pemangku kepentingan. Diskusi kelompok terarah dilakukan dengan teknik word café untuk mendorong keterlibatan dan pengayaan informasi dari seluruh peserta. Peserta diskusi berjumlah 15 orang, yang terdiri dari perwakilan dari Balai Besar Wilayah Sungai Pemalijuana, Perhutani, Bappeda, Dosen, pengusaha akomodasi, masyarakat lokal. 2. Wawancara mendalam dilakukan dengan para informan kunci yang ditentukan secara purposive berdasarkan pemahaman informan tentang kawasan Kedung Ombo.3. Kuesioner untuk mengumpulkan data tentang ketersediaan anggaran dan sumber daya manusia pariwisata dari para pemangku kepentingan. Kuesioner disusun dalam bentuk pertanyaan tertutup menggunakan rating scale dengan nilai 1-2 - 3-4- 5 (sangat kurangkurang-sedang-baik- baik sekali).

Analisa data dilakukan dengan menggunakan metode Qualitatif Comparative Analysis (QCA) yang dibantu dengan software Tosmana versi 1.54. QCA adalah cara baru untuk melakukan penelitian kausalitas tentang femomena sosial yang menggabungkan kekuatan metode kuantitatif dan kualitatif. QCA berguna untuk mengkaji bagaimana suatu outcome dapat dicapai melalui interaksi variabel atau faktor yang mempengaruhinya (Fauzi, 2019). QCA sangat sesuai untuk mempelajari situasi di mana peneliti memiliki keyakinan bahwa suatu outcome kemungkinan merupakan hasil dari beberapa jalur sebab akibat kondisi yang berbeda, dan suatu kondisi mungkin hanya munculefek kausalnya dalam kombinasi dengan kondisi lain (Devers et al., 2013). Metode QCA adalah metode perbandingan sistematis antar kasus (case base comparison) yang ditujukan untuk memahami faktor-faktor kualitatif apa (dalam istilah QCA disebut kondisi) yang mempengaruhi hasil yang diinginkan (outcome) (Fauzi, 2019).

Pada penelitian ini metode QCA digunakan untuk menemukan formula dan struktur kausalitas antara tingkat partisipasi pemangku kepentingan di kawasan Kedung Ombo dengan faktor-faktor pembentuknya, dan menentukan tipologi pemangku kepentingan berdasarkan kondisi dan tingkat partisipasi tersebut. Adapun tahapan analisa data berdasarkan pendekatan QCA disajikan pada Gambar 3.

\section{Hasil dan Pembahasan}

Diskusi kelompok terarah yang dilakukan telah menemukan empat faktor atau kondisi yang diidentifikasi memengaruhi partisipasi pemangku kepentingan di kawasan Kedung Ombo, yaitu: 1. pola pikir pemangku kepentingan terhadap pariwisata serta dampaknya terhadap ekonomi, sosial dan lingkungan, 2. kapasitas pemangku kepentingan dalam penyediaan, sumber daya manusia, anggaran, dukungan teknis, dan kemampuan dalam pengembangan atraksi wisata, 3. kualitas hubungan antar pemangku kepentingan, dan 4. keyakinan pemangku kepentingan bahwa keberadaan kawasan wisata Kedung Ombo dapat memenuhi kepentingan semua pihak.

Hasil diskusi, wawancara dan tanggapan responden atas pertanyaan-pertanyaan dalam kuesioner kemudian dielaborasi oleh peneliti menjadi data awal penelitian ini (Tabel 1). Dataset Tabel 1 menggambarkan minat berpartispasi dari 15 pemangku kepentingan berdasarkan empat faktor penentu partisipasi. Kondisi pemangku kepentingan diukur dengan skala 1-5 (sangat tidak baik - baik sekali), sedangkan data minat partisipasi 
pemangku kepentingan dinilai dengan skala 1 atau 0 (tidak berpartisipasi atau berpartisipasi).

Dari data awal diketahui kompleksitas hubungan antara kondisi dan partisipasi pemangku kepentingan dalam kasus ini. Untuk mendapatkan hubungan yang bermakna antara berbagai kondisi dan tingkat partisipasi yang bervariasi tersebut, maka data pada Tabel 1 dikalibrasi dengan nilai tertentu sebagai tresshold dan diolah oleh software Tosmana sebagai data QCA. Hasil proses kalibrasi ditunjukkan pada Tabel 1, dimana angka dalam kurung merupakan data awal (raw data), sedangkan angka di depannya (0 dan 1) adalah data hasil hasil kalibrasi.

Data hasil kalibrasi selanjutnya diolah menggunakaan metode multivalue analysis (mvQCA) untuk menggambarkan kombinasi kausal antara berbagai variasi kondisi dengan minat berpartisipasi. Pilihan jenis mvQCA berkaitan dengan jenisdata penelitian ini yang bersifat ordinal. Sesuai konsep QCA, mvQCA merupakan model yang paling tepat pada penelitian yang menggunakan data ordinal (Fauzi, 2019).

Hasil analisis mvQCA ditampilkan pada Tabel Kebenaran (Tabel 2) yang meringkas kombinasi hubungan kausalitas antara kondisi dengan minat berpartisipasi para pemangku kepentingan. Tabel Kebenaran berguna untuk mengidentifikasi kombinasi kondisi mana yang menyebabkan minat partisipasi positif, kombinasi mana yang menyebabkan minat partisipasi negatif atau kondisi mana yang menyebabkan minat berpartisipasi yang tidak tentu (ditunjukkan dengan "C"). Tabel Kebenaran membantu memperjelas dan menyederhanakan ekspresi kompleks dari konfigurasi sebab akibat dari kondisi yang menghasilkan minat berpatisipasi.

Berdasarkan Tabel Kebenaran diketahui 10 (sepuluh) variasi klasifikasi hubungan antara kondisi dengan minat berpartisipasi dari pemangku kepentingan di Kedung Ombo. Dari Tabel Kebenaran ini diketahui 11 unit (sebelas) pemangku kepentingan berminat berpartisipasi, sedangkan 4 (empat) pemangku kepentingan tidak berminat berpartisipasi. Hasil klasifikasi ini menjelaskan bahwa tidak ada sikap pemangku kepentingan terhadap partisipasi yang kontradiksi.

Fenomena khusus yang dapat diketahui dari Tabel kebenaran adalah tipologi dari pemangku kepentingan yang tidak berminat untuk berpartisipasi. Bappeda Boyolali dan Dinas PemudaOlah Raga Pariwisata Boyolali meskipun kedua lembaga pemerintah ini memiliki kondisi yang cukup baik pada kapasitas dan hubungan, namun tidak berminat untuk berpartisipasi. Berdasarkan hasil diskusi diketahui penyebab tidak minat berpartisipasi karena kedua lembaga tersebut sedang fokus pada pengembangan pariwisata di sisi selatan wilayah Kabupaten Boyolali (sedangkan kawasan Kedung Ombo berada di wilayah utara Kabupaten Boyolali).

Perguruan tinggi umum yang mempunyai pola pikir yang benar terhadap pariwisata dan dampaknya, mempunyai kapasitas yang memadai dan hubungan yang baik dengan pemangku kepentingan lain, namun tidak berminat berpartisipasi dalam pengembangan kawasan wisata Kedung Ombo. Hal tersebut dikarenakan mereka telah memiliki wilayah binaan lain dalam pengembangan pariwisata. Sedangkan para pengusaha tidak berminat 
berpartisipasi dalam pengembangan kawasan wisata ini dikarenakan investasi yang terlalu besar dan keterbatasan kapasitas lainnya. Berdasarkan temuan tersebut maka agar pengembangan kawasan wisata Kedung Ombo didukung oleh seluruh stakeholder, perlu dilakukan upaya untuk mengatasi kondisi yang terjadi pada pemangku kepentingan dengan tipologi 0 (tidak berminat berpartisipasi) ini.

Berdasarkan klasifikasi pemangku kepentingan padaTabel Kebenaran maka dapat diketahui 3 (tiga) alternatif struktur hubungan antara kondisi (faktor) pemangku kepentingan dengan minat untuk berpartisipasi dalam pengembangan kawasan wisata Kedung Ombo, sebagai berikut:

1. Partisipasi pemangku kepentingan ditentukan oleh faktor: 1) pola pikir yang benar tentang pariwisata dan dampaknya terhadap ekonomi, sosial dan lingkungan; 2) kapasitas pemangku kepentingan dalam penyediaan anggaran, sumber daya manusia, dukungan teknis, dan kemampuan dalam pengembangan atraksi wisata; 3) keyakinan pemangku kepentingan bahwa keberadaan kawasan wisata Kedung Ombo dapat memenuhikepentingan bersama pemangku kepentingan.

2. Partisipasi pemangku kepentingan ditentukan oleh keyakinan pemangku kepentingan bahwa keberadaan kawasan wisata Kedung Ombo dapat memenuhi kepentingan semua pihak.

3. Partisipasi Pemangku Kepentingan ditentukan oleh: 1) pola pikir yang benar tentang pariwisata dan dampaknya terhadap ekonomi, sosial dan lingkungan; 2) kualitas hubungan antar pemangku kepentingan.

Dari formulasi tersebut diketahui bahwa minat berpartisipasi akan muncul dengan sendirinya jika pemangku kepentingan mempunyai pola pikir yang benar terhadap pariwisata, mempunyai kapasitas sumber daya manusia, anggaran, dukungan teknis dan kemampuan dalam pengembangan atraksi wisata memadai dan keyakinan bahwa kawasan wisata kemampuan memfasilitasi kepentingan bersama seluruh stakeholder. Minat berpartisipasi juga akan muncul jika kawasan wisata Kedung Ombo nantinya mampu memfasilitasi kepentingan bersama para pemangku kepentingan, meskipun pola pikir dan kapasitas pemangku kepentingan dibawah tresshold yang ditentukan. Selanjutnya, minat berpartisipasi akan muncul jika pemangku kepentingan mempunyai pola pikir yang benar terhadap pariwisata dan mempunyai hubungan yang baik dengan pemangku kepentingan lainnya, meskipun nilai kondisi lainnya di bawah tresshold. Tipologi pemangku kepentingan yang telah diuraikan pada Tabel kebenaran dapat divisualisasi melalui diagram Venn pada Gambar 4.

Gambar 4 berguna untuk mengetahui nilai dari tiap-tiap kondisi (atau faktor) yang menentukan partisipasi serta posisi pemangku kepentingan terhadap kondisi tersebut. Dari Gambar 4 diketahui faktor pola pikir terbagi dalam dua sisi (garis vertikal), sisi sebelah kiri menunjukkan kondisi pola pikir dengan nilai 0 (negatif), sedangkan sisi sebelah kanan menunjukkan nilai "1" (positif). Garis tengah horizontal menggambarkan kondisi kapasitas pemangku kepentingan yang terbagi dalam dua bagian, yaitu sisi sebelah bawah menggambarkan kapasitas $=1$ (baik), dan sisi sebelah atas menggambarkan nilai kapasitas = 0 (buruk). Kotak di tengah horisontal menggambarkan kondisi hubungan, dimana area di dalam kotak tengah menggambarkan nilai hubungan = 1 (baik), sedangkan area di luar kotak tengah menggambarkan nilai hubungan $=0$ (buruk). Sementara, kotak tengah vertikal 
menggambarkan keberadaan kawasan dapat memfasilitasi kepentingan bersama, dimana area di dalam kotak tengah menggambarkan nilai kepentingan bersama $=1$ (dapat memfasilitasi kepentingan bersama), sedangkan area di luar kotak tengah vertikal menggambarkan nilai kepentingan bersama $=0$ (tidak dapat memfasilitasi kepentingan bersama).

Legenda di bawah diagram Venn menunjukkan nilai partisipasi, dimana nilai 0 menggambarkan tidak berminat untuk berpartisipasi, sedangkan nilai 1 menunjukkan berminat untuk berpartisipasi. Sedangkan simbol C menggambarkan sikap yang kontradiktif, artinya sebenarnya pemangku kepentingan tidak mempunyai kondisi yang memungkinkan untuk berpartisipasi namun berminat berpartisipasi. Sedangkan simbol R menunjukkan outcome remainder, yang berarti secara empiris kondisi pemangku kepentingan tidak mendukung untuk berpartisipasi namun secara teori memungkinkan.

Berdasarkan kaidah pemosisian pemangku kepentingan tersebut maka dapat diketahui posisi partisipasi para pemangku kepentingan pada pengembangan kawasan wisata Kedung Ombo. Sebagian besar pemangku kepenringan berada di area hijau yang berarti mendukung atau berminat berpartisipasi dalam pengembangan sesuai dengan kondisi masing-masing (dilihat dari kode-kode angka 0,1 pada area diagram Venn).

Fenomena khusus yang harus dicermati adalah sikap Bappeda Boyolali, Dinas Pemuda, Olah Raga, dan Pariwisata Boyolali, pengusaha, dan perguruan tinggi umum yang berada pada area 0 (warna merah muda), dengan kondisi, Bappeda Boyolali, Dinas Pemuda, Olah Raga, dan Pariwisata Boyolali pada kondisi 0010, pengusaha pada 0010 dan perguruan tinggi umum pada 1110. Posisi ini menunjukkan bahwa kelompok pemangku kepentingan ini tidak berminat untuk berpartisipasi. Hal ini disebabkan kondisi yang dipersyaratkan untuk dapat berpartisipasi nilainya 0 atau kurang dari nilai tresshold. Kondisi ini menggambarkan bahwa pola pikir pemangku kepentingan terhadap keberadaan kawasan dan efek ganda (multiplier effect) pariwisata wisata kurang baik, terkendala kapasitas, hubungan dengan pemangku kepentingan lainnya buruk, dan atau menilai bahwa pembangunan kawasan wisata Kedung Ombo tidak dapat memfasilitasi kepentingan bersama. Dari hasil wawancara diketahui bahwa para pemangku kepentingan ini kurang yakin terhadap keberhasilan pengembangan kawasan wisata ini karena selama ini mereka tidak dapat terlibat dalam pemanfaatan kawasan Kedung Ombo disebabkan pihak-pihak tertentu sangat dominan dan cenderung hubungannya tidak harmonis. Keterbatasan kapasitas baik pada sumber daya manusia pariwisata maupun fimansial juga menjadi faktor pemicu.

Bappeda Boyolali dan Dinas Pemuda, Olah Raga dan Pariwisata Boyolali adalah pemangku kepentingan dengan partisipasi 0 (tidak berpartisipasi), meskipun mempunyai kapasitas dan hubungan dengan pemangku kepentingan yang lain baik. Faktor yang mendorong lembaga ini tidak terlibat dalam pengembangan kawasan wisata Kedung Ombo adalah tidak tertampungnya kepentingan lembaga ini pada pengembangan kawasan wisata Kedung Ombo. Pemkab Boyolali saat ini berorientasi pada pengembangan wisata di sisi selatan wilayah (kawasan Kedung Ombo berada di wilayah utara). Hal ini telah dituangkan dalam rencana pembangunan jangka pendek maupun jangka menengah wilayah ini. 
Kondisi perguruan tinggi umum (bukan perguruan tinggi yang berfokus pada kepariwisataan), sebagaimana telah dijelaskan pada sesi sebelumnya bahwa mereka tidak berorientasi pada pengembangan kawasan Kedung Ombo, dikarenakan telah memiliki wilayah binaan di daerah yang lain. Wilayah binaan ini terkait dengan program kuliah kerja nyata mahasiswa maupun lokasi penelitian dan pengabdian kepada masyarakat bagi para dosen. Namun mereka akan mendukung pada saat kawasan wisata Kedung Ombo berhasil dikembangkan.

Bappeda dan Dinas Pemuda, Olah Raga dan Pariwisata Sragen, Bappeda Grobogan adalah pemangku kepentingan yang mempunyai nilai keterlibatan baik. Hal ini didukung oleh kondisi pola pikir, kapasitas dan keyakinan terhadap kemampuan kawasan wisata Kedung Ombo nantinya dapat memenuhi kepentingan Bersama. Demikian pula Perhutani KPH Telawah, Perhutani KPH Gundih dan masyarakat lokal. Pemosisian ini menjadi informasi yang sangat baik, bahwa lembaga-lembaga inilah yang seharusnya akan terlibat penuh dalam pengembangan kawasan wisata Kedung Ombo baik pada tahap perencanaan hingga tahap operasionalisasi kawasan. Balai Besar Wilayah Sungai (BWS) Pemali Juana sebagai pengelola waduk mempunyai posisi yang khas. Memiliki kapasitas teknis dan sumber daya manusia yang memadai, namun pada kondisi lain yaitu pola pikir dan hubungan kurang memadai (dibawah tresshold). Mengingat BBWS Pemali Utama merupakan pemangku kepentingan utama yang sangat besar pengaruhnya terhadap pengelolaan dan pemanfaatan waduk Kedung Ombo, maka diperlukan upaya-upaya khusus agar kondisi yang kurang dari tresshold dapat terus disesuaikan demi kepeberhasilan pengembangan kawasan wisata Kedung Ombo.

\section{Kesimpulan}

Studi ini menyelidiki faktor-faktor yang menentukan minat berpartisipasi pemangku kepentingan pada pengembangan kawasan wisata Kedung Ombo dengan metode QCA dan menjelaskan hubungan faktor-faktor tersebut dengan tipologi dari para pemangku kepentingan di kawasan ini. Minat berpartisipasi pemangku kepentingan ditentukan oleh 4 (empat) faktor, yaitu: 1) pola pikir pemangku kepentingan tentang pariwisata dan dampak ekonomi sosial dan lingkungan (multiplier effect) pada wilayah ini, 2) kapasitas pemangku kepentingan dalam penyediaan anggaran, sumber daya manusia, kemampuan pengembangan atraksi wisata, dan bantuan teknis, 3. hubungan antar pemangku kepentingan, dan 4. Keyakinan pemangku kepentingan bahwa keberadaan kawasan wisata Kedung Ombo mampu memfasilitasi kepentingan bersama para pemangku kepentingan.

Hasil pengolahan data dengan metode QCA menunjukkan bahwa terdapat tiga jalur terbentuknya minat partisipasi untuk memfasilitasi keragaman kondisi pemangku kepentingan, yaitu (1) untuk menghasilkan minat berpartisipasi harus didukung oleh pola pikir yang benar terhadap pariwisata, kapasitas yang baik dan keyakinan bahwa kawasan wisata Kedung Ombo mampu memfasilitasi kepentingan bersama para pemangku kepentingan; (2). minat untuk berpartisipasi dapat terwujud jika kapasitas pemangku kepentingan dalam penyediaan anggran, sumber daya manusia, dukungan teknis serta kemampuan mengembangkan produk wisata baik, meskipun kondisi yang lain kurang; dan (3) minat untuk berpartisipasi harus didukung oleh pola pikir yang benar terhadap pariwisata dan hubungan antar pemangku kepentingan yang baik. Temuan ini berimplikasi pada alternatif yang dapat dipilih untuk membangun dan mengembangkan faktor-faktor 
yang mempengaruhi tingkat partisipasi pemangku kepentingan sesuai dengan kondisi masing-masing pemangku kepentingan.

Hasil analisa Tabel Kebenaran menghasilkan tipologi pemangku kepentingan yang beragam yaitu pemangku kepentingan yang berminat berpartisipasi (1), pemangku kepentingan yang tidak berminat berpartisipasi ( 0 ) dan tidak ada pemangku kepentingan yang kontradiktif (C). Sebelas pemangku kepentingan berada pada tipologi berminat, sedangkan 4 (empat) lainnya tidak berminat. Temuan yang mengklasifikasikan pemangku kepentingan pada kluster 0 masih dapat didorong untuk terlibat dalam pengembangan ini dengan peningkatan pemahaman terhadap manfaat pariwisata yang sangat besar baik terhadap pemangku kepentingan itu sendiri maupun untuk lingkungan.

Untuk mendorong minat berpartisipasi maka, penting dilakukan beberapa perbaikan pada kondisi-kondisi yang mengakibatkan pemangku kepentingan berada pada tipologi tidak berminat untuk berpartisipasi. Kondisi yang terkait dengan pola pikir dapat diperbaiki dengan sosialisasi tentang pentingnya keberadaan pariwisata sebagai alternatif dalam peningkatan infrastruktur, ekonomi dan sosial untuk seluruh wilayah kabupaten. Melibatkan pemangku kepentingan dalam perencanaan juga dapat dilakukan sebagai cara untuk membuka cakrawala pemikiran. Pendekatan lain yang lebih terstruktur dapat dilakukan dengan melakukan studi banding ke wilayah yang telah berhasil mengembangkan pariwisata berbasis partisipasi.

Untuk meningkatkan kapasitas pemangku kepentingan dapat dilakukan dengan mengembangkan modal ventura dan mengembangkan sumber daya manusia pariwisata melalui pendidikan dan pelatihan. Sedangkan untuk meningkatkan hubungan antara pemangku kepentingan maka dapat dilakukan melalui peningkatan koordinasi baik secara vertikal maupun horizontal didukung oleh komunikasi yang persuasif. Sedangkan untuk mewujudkan kawasan wisata yang dapat memfasilitasi kepentingan bersama, maka menerapkan model perencanaan partisipastif dan kemitraan adalah upaya yang dapat ditempuh. Karena proyek pengembangan kawasan ini bersifat ex-ante maka dalam jangka pendek keraguan terhadap keberhasilannya masih cukup menonjol. Untuk mengoptimalkan potensi wisata Kedung Ombo, maka ide pengembangan ini perlu didukung baik oleh pengambil kebijakan yang berada pada kawasan Kedung Ombo, maupun Provinsi Jawa Tengah serta pemerintah pusat terkait dengan regulasi penggunaan kawasan di sekitar waduk maupun regulasi tata ruang wilayah lainnya. Akhirnya, hasil penelitian ini menjadi sumbangan pemikiran tentang bagaimana mengembangkan keterlibatan pemangku kepentingan yang menjadi salah satu syarat penting dalam melakukan pengembangan pariwisata.

\section{Ucapan Terima Kasih}

Penelitian ini merupakan bagian dari penelitian tentang Model Kelembagaan Pengembangan Kawasan Wisata Kedung Ombo yang didanai oleh Kementerian Pendidikan dan Kebudayaan Indonesia melalui hibah penelitian desentralisasi tahun jamak 2018-2020. Peneliti mengucapkan terima kasih atas dukungan tersebut. Peneliti juga menyampaikan terima kasih kepada BBWS Pemali Juana, Bappeda Kabupaten Grobogan, Bappeda Kabupaten Sragen dan Kabupaten Boyolali, Perhutani Gundih dan Perhutani Telawah atas dukungan dalam proses penelitian ini. 


\section{Daftar Pustaka}

Baggio, R., Scott, N., \& Cooper, C. (2010). Improving tourism destination governance : A complexity science approach Article information: Tourism Review, (November 2010). https://doi.org/10.1108/16605371011093863

Charleen, T., \& Forbes, K. (2014). Collaboration and stakeholder involvement for tourism development in Zimbabwe. Journal of Advanced Research in Management and Social Sciences, 3(1), 1-9.

Clarkson, M. B. E. (1995). A stakeholder framework for analyzing and evaluation corporate social performance. The Academy of Management Review, 20(1), 92-117.

Devers, K. J., Lallemand, N. C., Burton, R., Kahwati, L., Mccall, N., \& Zuckerman, S. (2013). Using Qualitative Comparative Analysis (QCA) to Study Patient-Centered Medical Homes, (September), $42 . \quad$ Retrieved from http://www.urban.org/publications/412969.html

Donaldson, T. \& Preston, L. E. (1995). The stakeholder theory of the corporation: Concepts, evidence, and implications. The Academy of Management Review, 20(1), 65-91.

Fathimath, A. (2015). The Role of Stakeholder Collaboration in Sustainable Tourism Competitiveness : The Case of Auckland, New Zealand, (April), 328.

Fauzi, A. (2019). Teknik Analisis Keberlanjutan (1st ed.). Jakarta: Gramedia.

Freeman, R.E.. McVea, J. (2001). Strategic management: A stakeholder approach. SSRN Electronic Journal. https://doi.org/DOI: 10.2139/ssrn.263511

Gray, B. (1989). Collaborating: Finding Common Ground for Multiparty Problems. JosseyBass.

Heger, T., \& Rohrbeck, R. (2012). Technological Forecasting \& Social Change Strategic foresight for collaborative exploration of new business fields. Technological Forecasting \& Social Change, 79(5), 819-831. https://doi.org/10.1016/j.techfore.2011.11.003

Hemaphan, P. (2017). Determinant of Stakeholder Participation Towards Sustainable Tourism Development: An Empirical Study Of Active Beach Destinations In Thailand. Sripatum Review of Humanities and Social Sciences, 17(1), 103-114. Retrieved from https://so05.tci-thaijo.org/index.php/spurhs/article/view/113155\%0A

Kala, D., \& Bagri, S. C. (2018). Barriers to local community participation in tourism development: Evidence from mountainous state Uttarakhand, India. Tourism, 66(3), 318-333.

Kurniasih, D.-- (2017). Model Penguatan Kelembagaan Pada Program Sanitasi Lingkungan Berbasis Masyarakat (Slbm) Di Kabupaten Banyumas (Suatu Pendekatan Collaborative Governance). Sosiohumaniora, 19(1), 1-7. https://doi.org/10.24198/sosiohumaniora.v19i1. 7888

Leal Filho, W., \& Londero Brandli, L. (2016). Engaging stakeholders for sustainable development. World Sustainability Series, (April 2018), 335-342. https://doi.org/10.1007/978-3-319-26734-0_21

Marzuki, A., Hay, I., \& James, J. (2012). Public participation shortcomings in tourism planning: The case of the Langkawi Islands, Malaysia. Journal of Sustainable Tourism, 20(4), 585-602. https://doi.org/10.1080/09669582.2011.638384

McComb, E. J., Boyd, S., \& Boluk, K. (2017). Stakeholder collaboration: A means to the success of rural tourism destinations? A critical evaluation of the existence of stakeholder collaboration within the Mournes, Northern Ireland. Tourism and 
Hospitality Research, 17(3), 286-297. https://doi.org/10.1177/1467358415583738

Miller, G., Rathouse, K., Scarles, C., Holmes, K., \& Tribe, J. (2010). Public understanding of sustainable tourism. Annals of Tourism Research, 37(3), 627-645. https://doi.org/10.1016/j.annals.2009.12.002

Nabiha, S., \& Hasliza, N. (2015). Tourism planning and stakeholders' engagement: The case of Penang Island. Problems and Perspectives in Management, 13(2), 269-276.

Ruhanen, L. (2012). Strategic visioning: integrating sustainable development principles into tourism destination planning. Acta Turistica, 24(2), 149-176. Retrieved from https://espace.library.uq.edu.au/view/UQ:271140

Stratigea, A. (2013). Participatory policy making in foresight studies at the regional level: A methodological approach. Regional Science Inquiry, 5(1), 145-161.

Tosun, C. (2000). Limits to community participation in the tourism development process in developing countries. Tourism Management, 21(6), 613-633. https://doi.org/10.1016/S0261-5177(00)00009-1

Tosun, C. (2006). Expected nature of community participation in tourism development. Tourism Management, 27(3), 493-504. https://doi.org/10.1016/j.tourman.2004.12.004

Tosun, C., Hatay, A., \& Timothy, D. J. (1998). Shortcomings in planning approaches to tourism development in developing countries : the case of, 352-359.

Turker, N., Alaeddinoglu, F., \& Can, A. S. (2016). The role of stakeholders in sustainable tourism development in Safranbolu, Turkey. Conference: 2016 International Conference on Hospitality, Leisure, Sports, and Tourism, (July), 415-426. Retrieved from

https://www.researchgate.net/publication/331000851_The_Role_of_Stakeholders _in_Sustainable_Tourism_Development_in_Safranbolu_Turkey

Waligo, V. M., Clarke, J., \& Hawkins, R. (2013). Implementing sustainable tourism: A multistakeholder involvement management framework. Tourism Management, 36, 342353. https://doi.org/10.1016/j.tourman.2012.10.008 


\section{Lampiran}

Tabel 1. Kondisi dan Minat Berpartisipasi Pemangku Kepentingan Pengembangan Kawasan Wisata Kedung Ombo

\begin{tabular}{lccccc}
\hline Pemangku Kepentingan & Pola pikir & Kapasitas & Hubungan & $\begin{array}{l}\text { Minat } \\
\text { Bersama }\end{array}$ & Partisipasi \\
\hline Perhutani Gundih & $1(4)$ & $1(3)$ & $1(4)$ & $1(4)$ & $1(1)$ \\
Perhutani Telawah & $14)$ & $1(4)$ & $1(4)$ & $1(4)$ & $1(1)$ \\
Bappeda Grobogan & $1(4)$ & $1(4)$ & $1(3)$ & $1(4)$ & $1(1)$ \\
Bappeda Boyolali & $0(2)$ & $1(4)$ & $0(3)$ & $0(2)$ & $0(0)$ \\
Bappeda Sragen & $1(5)$ & $1(4)$ & $0(2)$ & $1(5)$ & $1(1)$ \\
Dinpar Grobogan & $0(4)$ & $1(3)$ & $0(2)$ & $1(4)$ & $1(1)$ \\
Dinpar Boyolali & $0(2)$ & $1(3)$ & $1(3)$ & $0(2)$ & $0(0)$ \\
Dinpar Sragen & $1(4)$ & $1(3)$ & $0(2)$ & $1(4)$ & $1(1)$ \\
Masyarakat Lokal & $0(2)$ & $0(2)$ & $0(2)$ & $0(3)$ & $1(1)$ \\
Pengusaha & $0(3)$ & $0(2)$ & $1(3)$ & $0(3)$ & $0(0)$ \\
Perguruan Tinggi Umum & $1(4)$ & $1(4)$ & $1(3)$ & $0(2)$ & $0(0)$ \\
Perguruan Tinggi & $1(4)$ & $0(2)$ & $1(3)$ & $0(3)$ & $1(1)$ \\
Pariwisata & $0(2)$ & $0(1)$ & $0(2)$ & $1(4)$ & $1(1)$ \\
Pemerintah Desa & $0(3)$ & $0(1)$ & $1(3)$ & $1(4)$ & $1(1)$ \\
Karang Taruna & \multicolumn{5}{c}{ Sumber: Pengolahan Data, 2020 }
\end{tabular}

Tabel 2. Tabel Kebenaran Partisipasi Pemangku Kepentingan Pada Pengembangan Kawasan Wisata Kedung Ombo

\begin{tabular}{cccccl}
\hline $\begin{array}{l}\text { Pola } \\
\text { Pikir }\end{array}$ & Kapasitas & Hubungan & $\begin{array}{r}\text { Kepentingan } \\
\text { Bersama }\end{array}$ & Partisipasi & Pemangku Kepentingan \\
\hline 0 & 0 & 0 & 0 & 1 & Masyarakat lokal \\
\hline 0 & 0 & 0 & 1 & 1 & Pemerintah Desa \\
\hline 0 & 0 & 1 & 0 & 0 & Pengusaha \\
\hline 0 & 0 & 1 & 1 & 1 & Karang Taruna \\
\hline 0 & 1 & 0 & 0 & 1 & BBWS Pemalijuana \\
\hline 0 & 1 & 1 & 0 & 0 & $\begin{array}{l}\text { Bappeda Boyolali, } \\
\text { Dinas Pemuda Olah Raga } \\
\text { Pariwisata Boyolali }\end{array}$ \\
\hline 1 & & & & 1 & $\begin{array}{l}\text { Perguruan Tinggi } \\
\text { Pariwisata }\end{array}$ \\
\hline 1 & 0 & 1 & 0 & 1 & $\begin{array}{l}\text { Bappeda Sragen, } \\
\text { Dinas Pemuda Olah Raga } \\
\text { Pariwisata Sragen } \\
\text { Dinas Pemuda Olah Raga } \\
\text { Pariwisata Grobogan }\end{array}$ \\
\hline 1 & 1 & 0 & 1 & & Perguruan Tinggi Umum \\
\hline 1 & & & & & $\begin{array}{l}\text { Perhutani Gundih, } \\
\text { Perhutani Telawah, } \\
\text { Bappeda Grobogan }\end{array}$ \\
\hline
\end{tabular}



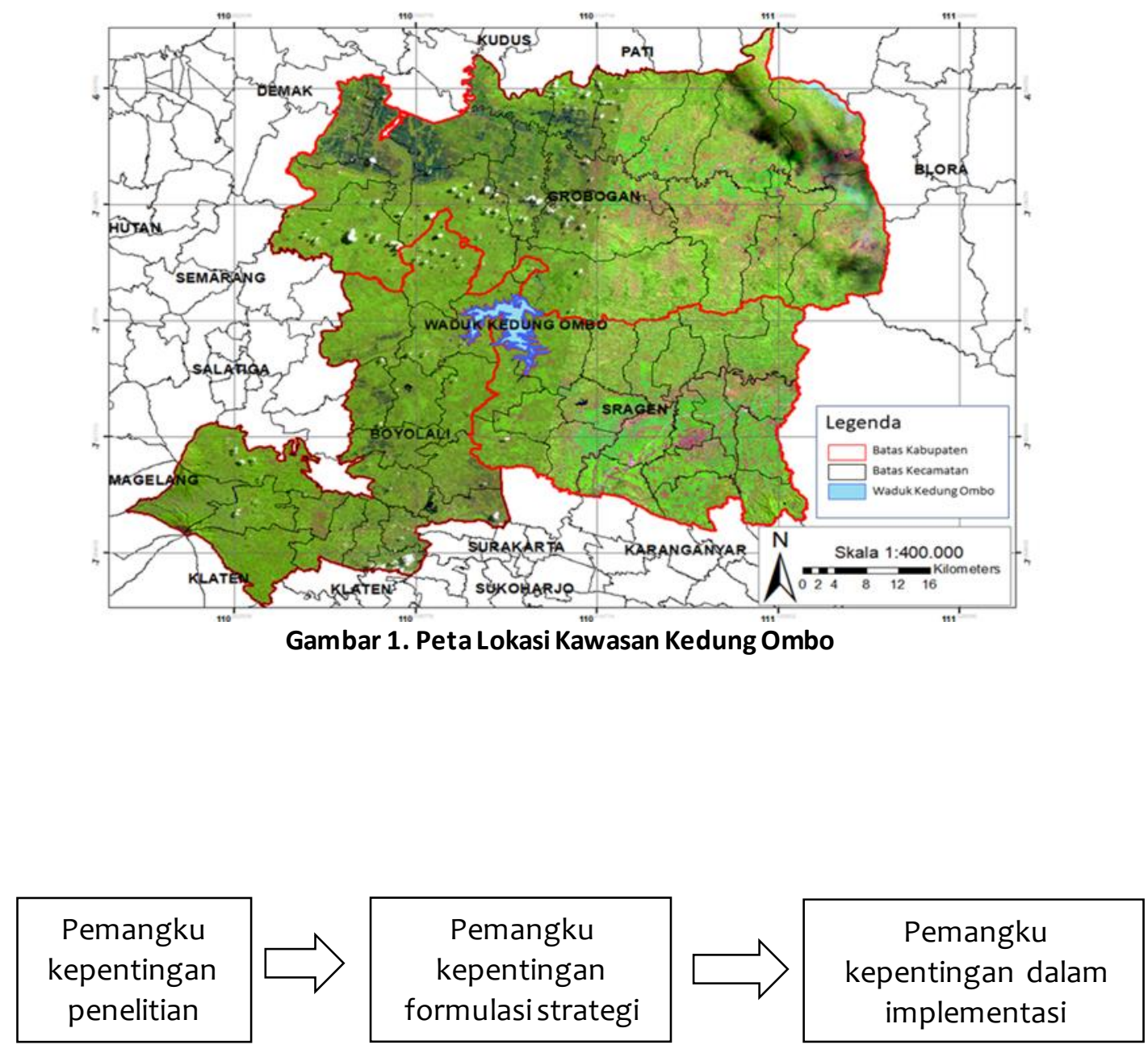

Gambar 2. Pemangku Kepentingan Dalam Pengembangan Pariwisata

(Sumber: Charleen and Forbes, 2014)

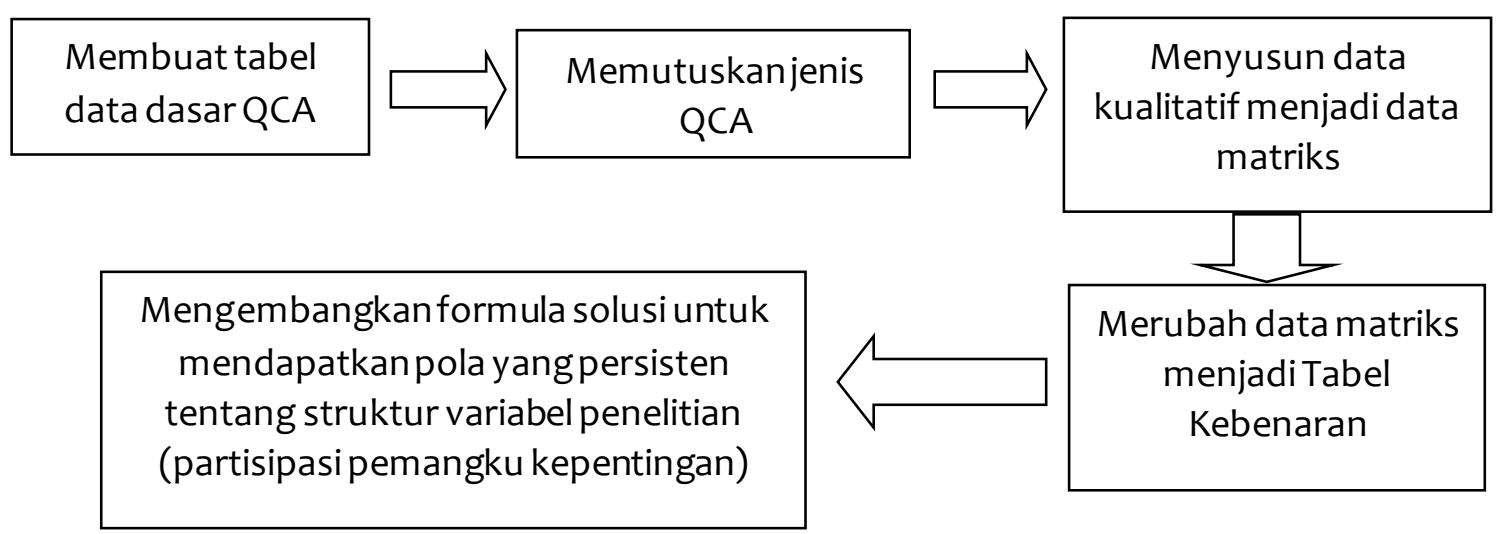

Gambar 3. Tahapan Metode QCA

(Sumber: Fauzi, 2019) 
Krisna Sella, Mohamad Yusuf

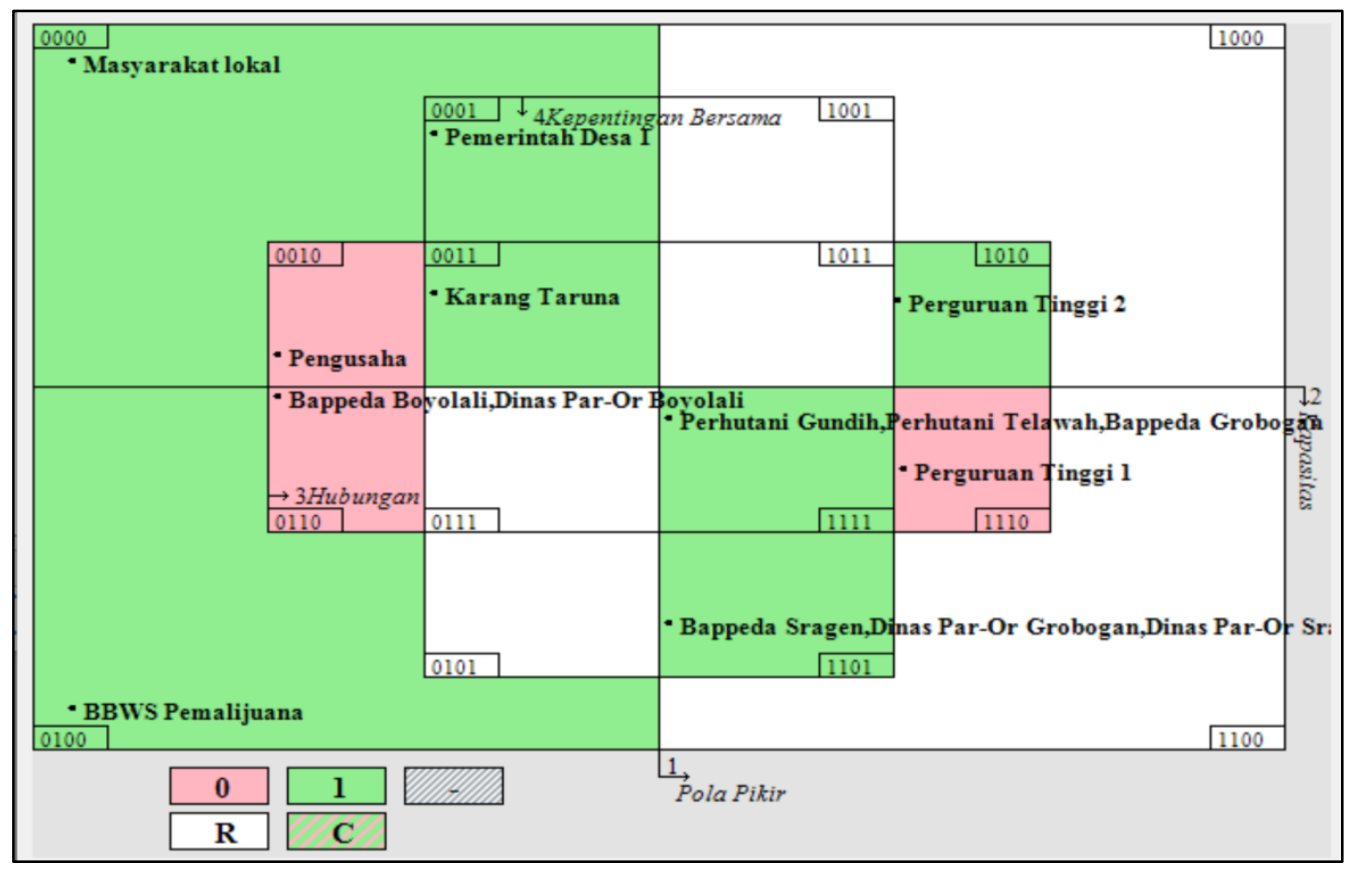

Gambar 4. Diagram Venn Partisipasi Pemangku Kepentingan

(Sumber: Pengolahan Data, 2020) 